\title{
STUDENTS' PERCEPTION AND ATTITUDE TOWARDS ENTREPRENEURSHIP IN HO CHI MINH CITY: A CASE STUDY AT HO CHI MINH CITY CADRE ACADEMY
}

\author{
Trinh Yen Vy \\ Ho Chi Minh City Cadre Academy, Ho Chi Minh City, Vietnam \\ E-mail: vytrinhyen2021@gmail.com \\ Pham Ngoc Van Anh \\ Ho Chi Minh City Cadre Academy, Ho Chi Minh City, Vietnam \\ E-mail: ngocvananhpham2002@gmail.com \\ Phan Thi Hue Anh \\ Ho Chi Minh City Cadre Academy, Ho Chi Minh City, Vietnam \\ E-mail: hueanhphan2002@gmail.com
}

\begin{abstract}
In the context of the 4th industrial revolution, it is becoming increasingly difficult to ignore entrepreneurship. Starting a business is expected to create economic growth, make positive contributions to socio-economic development. It is gradually emerging and becoming a topic of much interest from researchers and businesses. So far, however, there has been little discussion about student entrepreneurship. The present research examines the perception and attitude of Ho Chi Minh City students towards entrepreneurial activity through a case study at Ho Chi Minh City Cadre Academy. Specifically, the study addresses the following questions: 1/attitude towards entrepreneurship 2/ reasons for students to be confident to start a business 3/ reasons for students to be not self-confident to start a business. This study employed questionnaires and in-depth interviews as methods to come to the results of the research. The authors selected a nonprobability sampling of 240 students in classes of 5 majors at Ho Chi Minh City Cadre Academy for the questionnaire. The findings of this study suggest that the percentage of students who are not confident in starting a business is higher than that of those who are self-confident. The study also finds out the social factors affecting students' confidence in starting a business and why they are not confident of entrepreneurship.
\end{abstract}

Keywords: Attitude, Entrepreneurship, Perception, Students.

\section{INTRODUCTION}

In the context of our country's strong integration with the world economy, especially with the development of industrial achievements in the 4.0 era, it requires a young workforce fully equipped with knowledge and skills. In that situation, student entrepreneurship is also gradually emerging and becoming a topic of much interest from large and small businesses. Starting a business is expected to create economic growth, make positive contributions to socio-economic development, meet the increasing and diverse needs of society, and create many jobs for the community and 
society. However, most Vietnamese students have difficulty in entrepreneurship. They do not distinguish clearly between starting a business and setting up a business. $66.6 \%$ of Vietnamese students currently do not know about entrepreneurial activities, the proportions of students who know about entrepreneurial programs only account for $33.4 \%$, and the actual rate of students participating in the entrepreneurial programs only reaches $0.016 \%$. The education system has not focused on arousing entrepreneurial spirit. Students graduating from high school are not equipped with the basic principles of economics and have a practical approach to business. Most students graduating from high school, even many after graduating from university still do not have a full perception of entrepreneurial activities. They are not active in setting up a business, creating opportunities for themselves. Moreover, education and training programs only focus on equipping knowledge and skills for students to become an employee rather than an owner. Every year about 400,000 students' graduate, but up to 225,000 students cannot find employment. According to the survey data at 1,500 start-ups by the National Start-up Association, most of the new graduates in the country have not met the expectations of start-up activities (Decision No. 1665/QD-TTg of the Prime Minister, 2017)

Stemming from the above situation, the authors have chosen the topic: Entrepreneurial perception and attitude of students in Ho Chi Minh City (through a case study at Ho Chi Minh City Cadre Academy), with the hope of providing a scientific understanding, thereby contributing to solving the problems posed in practice about entrepreneurship of students today.

Deepening a relatively comprehensive and systematic understanding of the perception of entrepreneurship of students at Ho Chi Minh City Cadre Academy, thereby contributing to clarifying more about this social phenomenon in both theoretical and practical aspects.

Theoretically, the study aims to systematize the factors forming a concept "Perception of an entrepreneurial attitude of students in Ho Chi Minh City (through a case study at Ho Chi Minh City Cadre Academy). With this research results, the student's perception of entrepreneurial attitude becomes complete and systematic.

Practically, the study aims to identify the components for the perception of entrepreneurship attitude of students in HCMC Ho Chi Minh City, students at Ho Chi Minh City Cadre Academy, as well as provide scientific arguments for the research, and solve problems raised at the Ho Chi Minh Cadre Academy.

\section{Perspectives on Entrepreneurial Attitude of Students}

When it comes to the entrepreneurial attitude, most people will think a lot about capital, status, role, and importance of entrepreneurship. That has partly influenced the view of most students who want to start a business. The Government's project "Supporting entrepreneurship for university students by 2025" defines the goal as a strong shift in the educational process from mainly providing knowledge to developing comprehensively students' competencies and qualifications. Students' learning will, therefore "go hand in hand with practice"; closely linking theory with practice. Supporting students in innovative entrepreneurship is one of the important and practical solutions to effectively implement the Central guiding point of view. Carrying out the tasks assigned by the Party and the Government, over the past time, the Ministry of Education and Training, in collaboration with central and local ministries, has actively implemented many activities and solutions to support students in entrepreneurship. It is also necessary to affirm that entrepreneurship is the result of a process of educational innovation from high school to college, not just the name of a project or movement. Only in this way can this activity keep its significance 
(Decision No. 1665/QD-TTg of Prime Minister, 2017). The study "The reality of some factors affecting the entrepreneurial spirit of students in Hanoi" by Luong Ngoc Minh has shown that the status of students' entrepreneurial spirit is at a low level and pointed out the factors affecting the process of students' entrepreneurship in Hanoi (Minh, 2019). Duong Ngoc Hong's study on "The reality of innovative start-ups in Vietnam - difficulties and solutions", also outlined four factors that can be considered more favorable for start-ups in Vietnam. They are four indicators in which Vietnam has the highest-ranking: the dynamism of the domestic market, culture and social norms, infrastructure, and openness of the domestic market. This study also showed the relationship between students' perception and thinking associated with entrepreneurial intention. The study highlighted the difficulties and challenges in the current situation that students and startups have been facing. It offered advice and solutions to help those who want to start a business or those who have started a business to be well prepared and avoid making mistakes in starting their own business.

The study "Examining the relationship between entrepreneurial perception, intention, and behavior of Vietnamese students" by Nguyen Quang Thu and Tran The Hoang - Ho Chi Minh City University of Economics and Ha Kien Tan - Binh Duong University of Economics and Technology affirmed that the perceived feasibility factor (entrepreneur's competence) and action intention have a great impact on entrepreneurial behaviors. This factor suggests that students need to experience and persevere in investing in their startup ideas through training activities at university to strengthen their entrepreneurial competencies. The study also found out that to be able to start a business, students need to be equipped with a lot of relevant entrepreneurial knowledge such as knowledge of product/service markets, sales, and marketing, competitors, technology, human resources, laws, especially finance, etc. If students have ideas, and consistently find a market for their products/services, but they are lack capital, their ideas are just ideas until they can make them happen. Therefore, if there is no or little capital to start a business, students can mobilize external capital if they want to start a business. This study also showed that besides teaching finance, economics, and management, students must be taught psychology to be able to deal with failures and take risks (Thu, Hoang, \& Tan, 2018).

The research article "The role of the relationship between students' entrepreneurial intentions and behavior" by Nguyen Quang Thu, Tran The Hoang, and Ha Kien Tan shared the same point of view. This study examined the relationship between intention and entrepreneurial behaviors of final year students in Southern Vietnam, including Ho Chi Minh City, Binh Duong Province, and Dong Nai Province through the mediator element that is entrepreneurial commitment. These relationships are determined by a sample of 248 students who have been starting their businesses. The study results revealed that entrepreneurial intention has a direct positive, impact on entrepreneurial behaviors, but its positive impact is weaker than entrepreneurial commitment. The entrepreneurial commitment has a positive impact on entrepreneurial intention. Furthermore, it is conceivable that entrepreneurial commitment plays a significant moderating role in the relationship between intention and entrepreneurial behavior (Thu, Hoang, \& Tan, 2020).

In the study "Factors affecting young people's entrepreneurial intention in Vietnam" by Nguyen Anh Tuan, it mentioned and generalized the factors affecting the thoughts and attitude of young people about entrepreneurship. A multiple linear regression method was applied to determine the relationship between entrepreneurial intentions and potential conditions. This study has shown what needs to be done to promote the desire to succeed and challenge, entrepreneurial attitude and perception control behavior, and creativity have many benefits in increasing the 
intention to start a business of Vietnamese youth (Tuan, 2018). Report "Vietnam - Good land for startups: Why not?" of the Vietnam Chamber of Commerce and Industry, the US Agency for International Development has given specific arguments that to have a good attitude about entrepreneurship, it is first necessary to understand the concept of entrepreneurship correctly, which is a prerequisite for determining the right audience and goals, a premise to ensure the effectiveness of support policies and programs to promote the entrepreneurial spirit. On the contrary, incorrect or incomplete understanding of this concept will lead to misleading support policies and programs, wasting resources, and being unable to promote internal resources. This report also makes the argument that social attitudes have a direct influence on the entrepreneurial spirit and decision to start a business of people, especially young people. The policies and laws of a country will directly affect the creation of a culture of entrepreneurship and innovation. In reality, countries with a positive attitude and support for entrepreneurship will have a higher level of entrepreneurship and innovation (Vietnam Chamber of Commerce and Industry, US Agency for International Development (2018). Regarding the research paper "Some factors affecting students' intention to start a business" by Truong Duc Thao and Nguyen Trung Thuy Linh, these authors have analyzed the attitude towards entrepreneurship. They believed that those who have a positive attitude and a passion for the business will have a positive impact on starting a business and making it easier to achieve success. The study has provided information and perspective on how the attitude will affect entrepreneurship and promoted the spirit and movement of entrepreneurship for Vietnamese students (Thao \& Linh, 2019)

School is considered as a second home, containing a lot of valuable knowledge and foundation, bringing a new space for students and also a place to help students make their dreams and ambitions come true. School is one of the factors that have a great influence on the students' perception of entrepreneurship. This is clearly shown through the study "The role of entrepreneurship education for students' intention to start a business", Quang (2017). Similarly, the study "Strengthening propaganda to raise awareness about entrepreneurship for students" was carried out by Dong Nai Start-up group. In addition, the study "The role of education in the perception and intention of starting a business of students at Binh Duong University of Economics and Technology" conducted by Ha Kien Tan, Nguyen Ngoc Diem \& Nguyen Trong Minh (Tan, Diem, \& Minh, 2019). Hang and Tung (2019) conducted a study "The influence of entrepreneurship training on entrepreneurial intention - a case study at the University of Danang". In the Proceedings of the national scientific conference chaired by the National Economics University, there was a discussion "creative start-ups in Vietnam, opportunities for sustainable development" by Dang Thi Kim Thoa and Nguyen Ngoc Diep. The study "Discussion on entrepreneurship activities in Vietnam" was carried out by Nguyen Thi Thu Ha. Luong Thu Ha had a study on "The topic of financial management in starting a business". These authors have shown that start-up activities are very rich and diverse in types, helping us to have activities suitable for each type in a specific context. The studies also show students' attitudes to the difficult problems and obstacles that entrepreneurs face in building their business models, business forms, and start-up in the digital era. The above are summaries of the achievements and views of previous researchers, about the forms and contents of entrepreneurship and the role of schools and universities in entrepreneurship.

Reviewing previous studies and documents partly helps the authors find out the missing gaps that need to be filled in and this is also a premise to help inherit the achievements of those studies. Our point of view on students' entrepreneurial attitude will be presented in Figure 1. 


\section{The Entrepreneurial Attitude of Students}

According to the author of this study, students' attitude about entrepreneurship is the specific behavior that students engage in entrepreneurship. It plays a critical role in deciding to start a business of students today. The expression of entrepreneurial attitude is being confident of starting a business, or not being confident of starting a business.

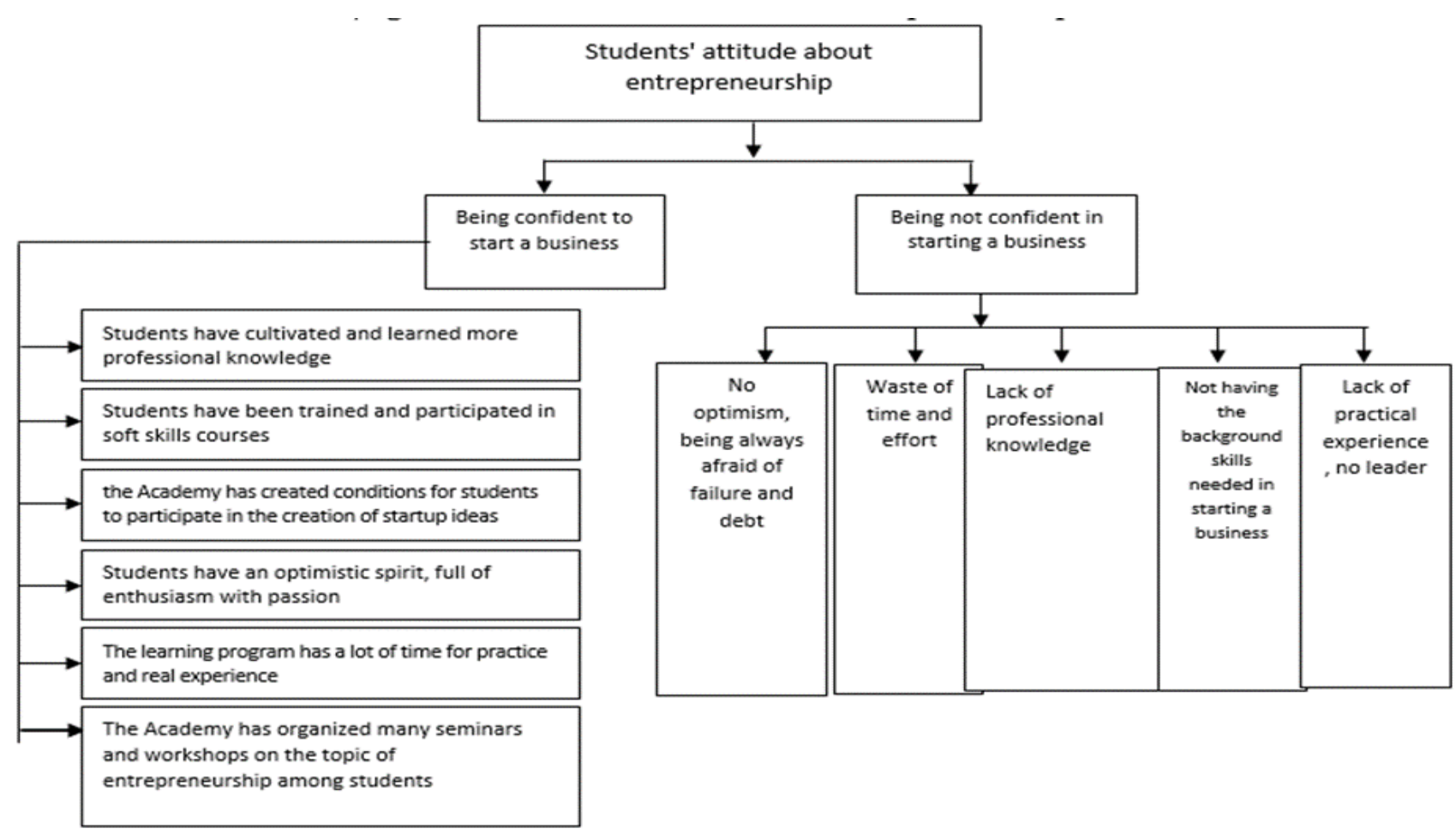

Figure 1. Students' attitude about entrepreneurship

Regarding confidence in starting a business, the indicators are these: 1/ Having cultivated and learned more professional knowledge and participation; 2/ Training soft skills classes; 3/ Because the Academy creates conditions for students to have creative ideas, this indicator tells us whether students participate in startup activities organized by the Academy; 4/ Have an optimistic spirit, full of enthusiasm with passion; 5/ The learning program has plenty of time for practice and practical experience; 6/ Organize many seminars and workshops on the topic of entrepreneurship among students.

On the contrary, some students are not confident in starting a business. It includes the following indicators: 1/ There is no optimism, always afraid of failing in debt; 2/ Waste of time and effort; 3/ Lack of professional knowledge; 4/ Do not have the necessary skills in starting a business; 5/ Lack of practical experience, no leader is what hinders students in the process of starting a business.

\section{Document Research}

\section{METHODS}

The authors have analyzed and synthesized the concepts, theoretical approaches, contents, and methods of related works and published statistical data sources. These include: i) Books, printed newspapers, online newspapers, scientific journals and research works at national conferences, ...; 
ii) Decrees, schemes of the Government, ministries, branches, and legal documents related to the research object.

\section{Questionnaire}

A questionnaire is a method of collecting information through the use of a prepared questionnaire by the researcher to give instructions on how to answer the questions, and the respondents will write their answers. The surveyors will record the answers and process the information, specifically as follows:

(1) The sampling process: Both quantitative and qualitative methods were used. In the current study, the authors selected a non-probability sampling of 240 students in classes of 5 majors at Ho Chi Minh City Cadre Academy.

(2) In terms of design, the questionnaire includes two parts: (i) Information on respondents' characteristics; (ii) Information on students' entrepreneurial attitude. These contents are arranged according to the detailed structure of the topic, from general to detailed level, paying attention to the psychological factor of the students who answered the questionnaire.

(3) Regarding respondents to the questionnaire: To ensure the accuracy of the information, the respondents must be students of 5 majors at Ho Chi Minh Cadre Academy, including Social Work, Political Science, Party Construction and State Government, Law, State Management.

(4) How to conduct the survey: First, the author contacted the training department to ask for permission to interview students in classes of the five mentioned majors. Then, the authors met the monitors of these classes to ask for permission to survey the perception and attitude of students about entrepreneurship. The information collection process is always under the supervision of the authors to minimize errors.

(5) Regarding processing survey results: After the data collection process, the data were checked, coded, entered, and processed according to the requirements of the study. The data analysis for this study was conducted through SPSS 20.0 software.

(6) Regarding the characteristics of the respondents, they are classified according to the following five social groups:

Table 1. Social groups

\begin{tabular}{|c|l|c|c|}
\hline \multicolumn{2}{|c|}{ Social groups } & Quantity (N) & Rate (\%) \\
\hline \multirow{3}{*}{ 1. Gender } & Female & 159 & 66.3 \\
\cline { 2 - 4 } & Male & 81 & 33.8 \\
\cline { 2 - 4 } & Total & 240 & 100.0 \\
\hline \multirow{3}{*}{ 2. Region } & Coming from the North & 28 & 11.7 \\
\cline { 2 - 4 } & Coming from the Central region & 39 & 16.3 \\
\cline { 2 - 4 } & Coming from the South & 173 & 72.1 \\
\hline \multirow{3}{*}{3. Major } & Social Work & 48 & 20.0 \\
\cline { 2 - 4 } & Political Science & 48 & 20.0 \\
\cline { 2 - 4 } & Party Construction and State Government & 48 & 20.0 \\
\cline { 2 - 4 } & Law & 48 & 20.0 \\
\cline { 2 - 4 } & State Management & 68 & 20.0 \\
\hline \multirow{3}{*}{ 4. Student } & Freshman & 60 & 25.0 \\
\cline { 2 - 4 } & Sophomore & 60 & 25.0 \\
\cline { 2 - 4 } & Junior & & 25.0 \\
\hline
\end{tabular}




\begin{tabular}{|c|l|c|c|}
\hline & Senior & 60 & 25.0 \\
\hline \multirow{2}{*}{$\begin{array}{c}\text { 5. Age } \\
\text { group }\end{array}$} & From 19 to 20 years old & 119 & 49.6 \\
\cline { 2 - 4 } & From 21 to 27 years old & 121 & 50.4 \\
\hline
\end{tabular}

\section{In-Depth Interview}

In-depth interviews are a qualitative data collection method that allows direct interaction between interviewers and interviewees. Interviewing is a method widely used in surveys and scientific research to collect and explore information from interviewees.

During the research, we used the in-depth interview method with 10 students representing each major. To find out and collect in-depth information on students' perception and attitude of entrepreneurship, the advantages and disadvantages as well as the factors affecting the perception of students in entrepreneurial activities, which takes into account the factors such as gender, age, major, student year of students at the Academy. On that basis, some recommendations are proposed to improve students' perception of starting a business at the Ho Chi Minh City Cadre Academy.

\section{Other Methods}

In addition to the above initial data collection methods, for the purpose of the study, the authors also use a series of general methods in scientific research such as: analysis and synthesis, deductive and inductive, logical and compare methods.

\section{RESULTS}

A correct perception of entrepreneurship will help students have more positive attitudes in their entrepreneurial activities. Therefore, in this study, it is necessary to focus on clarifying the students' attitudes about starting a business, as well as the reasons for performing these activities in the current context at the Academy of Cadres. How to start a successful business and why?

Being ready to start a business

In the current context, students' entrepreneurial attitude is an important activity in expressing their entrepreneurial behaviors. The author's survey shows two indicators of students' attitudes when starting a business, including $1 /$ Confident in starting a business, $2 /$ not confident in starting a business. This attitude is an important factor for them to join their entrepreneurial activities successfully or not. The research team's survey revealed:

Table 2. Students' attitude to be ready to start a business, by majors

\begin{tabular}{|c|c|c|c|c|c|c|c|c|c|c|c|c|}
\hline \multirow{3}{*}{ Being ready to start a business } & \multicolumn{12}{|c|}{ Majors } \\
\hline & \multicolumn{2}{|c|}{ Social work } & \multicolumn{2}{|c|}{ Politics } & \multicolumn{2}{|c|}{\begin{tabular}{|c|} 
Party \\
Construction \\
and State \\
Government
\end{tabular}} & \multicolumn{2}{|c|}{ Law } & \multicolumn{2}{|c|}{$\begin{array}{c}\text { State } \\
\text { Management }\end{array}$} & \multicolumn{2}{|c|}{ Total } \\
\hline & $\mathrm{N}$ & $\%$ & $\mathrm{~N}$ & $\%$ & $\mathrm{~N}$ & $\%$ & $\mathrm{~N}$ & $\%$ & $\mathrm{~N}$ & $\%$ & $\mathrm{~N}$ & $\%$ \\
\hline $\begin{array}{l}\text { 1. Being confident in starting a } \\
\text { business }\end{array}$ & 19 & 39.6 & 15 & 31.3 & 30 & 62.5 & 20 & 41.7 & 26 & 54.2 & 110 & 45.8 \\
\hline $\begin{array}{l}\text { 2. Being not confident in starting a } \\
\text { business }\end{array}$ & 29 & 60.4 & 33 & 68.8 & 18 & 37.5 & 28 & 58.3 & 22 & 45.8 & 130 & 54.2 \\
\hline $\begin{array}{l}\text { Total } \\
\end{array}$ & 48 & 100.0 & 48 & 100.0 & 48 & 100.0 & 48 & 100.0 & 48 & 100.0 & 240 & 100.0 \\
\hline
\end{tabular}

Source: Primary source 
As the above comment shows, there is a gap from perception to attitude. The perception is an orientation, the attitude is the behavior that performs the entrepreneurial activities. Students' perceptions of the entrepreneurial activities at the Academy are generally very good. However, Table 2 shows the attitude of students' readiness to start a business, in indicator No. 1/ Being confident of starting a business accounted for $45.8 \%$, lower than indicator $2 /$ Being not confident of starting a business represented 54.2\%. The number of students of Ho Chi Minh Cadre Academy who are not ready for entrepreneurship is less than half of that is ready. And the authors continued to analyze the correlations between social groups.

When looking at social groups, specialized groups, also in table 2 with Significant equals to 0.018 , it shows that these groups have differences in their readiness to start a business. In indicator 1/ Being confident of starting a business, the Party construction \& State government accounted for $62.5 \%$ higher than the State management at $54.2 \%$, Law group accounted for $41.7 \%$, and social work group accounted for $39.6 \%$. The lowest is the Political science group, accounting for $31.3 \%$. In Indicator $2 /$ Being not confident of starting a business, the political science group accounted for a higher proportion at $68.8 \%$, the social work group accounted for $60.4 \%$, the Law group accounted for $58.3 \%$, the State management group accounted for $45.8 \%$, the lowest rate is the group of Party construction and state management with the proportion of $37.55 \%$. Regarding the gender group, with Significant equals to 0.03, it reveals that there is a difference between this groups in an attitude of starting a business. In indicator No. 1/ Being confident of starting a business, the proportion of men accounted for $55.6 \%$, higher than that of women at $40.9 \%$. Indicator 2/ Being not confident of starting a business, the proportion of women is $59.1 \%$, the proportion of men is 44.4. Why is there this difference? To find out about this disparity, the authors interviewed a female student. She said: "I majored in political science, so I am more politically inclined and I have no financial resources and intention to start a business." (Female student, majoring in politics, 20 years old). Another male student stated: "In the process of going to university, I experienced many jobs as well as worked in many different fields. Each profession has given me the knowledge to accumulate for my future. Let me show you a little: I'm the owner of a fruit tea truck. Please buy and support me" (Male student, major of Party construction and state government, 21 years old). However, in the group of regions, Significant equals 0.191, in age group, Significant equals 0.239, in the group of student year Significant equals 0.503, showing that there is no difference between groups in attitude to start a business. That is, the perception of entrepreneurial behavior is relatively similar for these groups. The authors would like to take two indicators to carry out the evaluation and analysis process. In indicator 1/ Being confident of starting a business, fourth-year students accounted for $51.7 \%$, higher than the third year at $48.3 \%$, the first year accounted for $45.0 \%$, the lowest was the second year at $38.3 \%$. Or in indicator $2 /$ Being not confident of starting a business, second-year students accounted for $61.7 \%$, higher than that of the first year at $55.0 \%$, the third year accounted for $51.7 \%$ and the fourth year represented $48.3 \%$. Studying deeper into this issue, the authors interviewed a female student, saying: "Whether you are ready to do a certain job or not depends on each individual. Even if you love doing it but you are afraid of taking risks and challenges, you still cannot confidently do that job" (Female student, State Administration major, 20 years old). Thus, through the above analysis, we can see that more than half of the students are not ready to start a business. This is due to some factors, which the authors will present in the next section. 


\section{Reasons for being Confident of Starting a Business}

Starting a business always requires the entrepreneur to be confident in the connection of resources, or the application of knowledge with the surrounding practical activities. This confidence will lead them to success and as above shows that up to $45.8 \%$ of students think that they are confident enough to start a business (see Table 2 above). What is the reason to motivate their behavior? The survey of the authors showed that there are 6 indicators showing the reason for this confidence: $1 /$ Students have cultivated and learned more professional knowledge; $2 /$ Students have been trained and participated in soft skills classes; 3/ The Academy has created conditions for students to participate in creating ideas of entrepreneurship; 4/ Students have an optimistic spirit, full of enthusiasm with passion; 5/ The learning programs have a lot of time for practice and practical experience; 6 / The Academy has organized many seminars and workshops on the topic of skills in students. This will make students more confident in the process of entrepreneurship. It can be shown as follows:

Table 3. Reasons for students' confidence in starting a business, by majors

\begin{tabular}{|c|c|c|c|c|c|c|c|c|c|c|c|c|}
\hline \multirow{3}{*}{$\begin{array}{l}\text { Reasons for being confident to start a } \\
\text { business }\end{array}$} & \multicolumn{12}{|c|}{ Major } \\
\hline & \multicolumn{2}{|c|}{ Social Work } & \multicolumn{2}{|c|}{ Politics } & \multicolumn{2}{|c|}{$\begin{array}{l}\text { Party } \\
\text { Construction } \\
\text { and State } \\
\text { Government }\end{array}$} & \multicolumn{2}{|c|}{ Law } & \multicolumn{2}{|c|}{$\begin{array}{c}\text { State } \\
\text { management }\end{array}$} & \multicolumn{2}{|c|}{ Total } \\
\hline & $\mathrm{N}$ & $\%$ & $\mathrm{~N}$ & $\%$ & $\mathrm{~N}$ & $\%$ & $\mathrm{~N}$ & $\%$ & $\mathrm{~N}$ & $\%$ & $\mathrm{~N}$ & $\%$ \\
\hline $\begin{array}{l}1 \text { Students have cultivated and learned } \\
\text { more professional knowledge }\end{array}$ & 13 & 68.4 & 5 & 35.7 & 22 & 73.3 & 17 & 85.0 & 16 & 61.5 & 73 & 67.0 \\
\hline $\begin{array}{l}2 \text { Students have been trained and } \\
\text { participated in soft skills courses }\end{array}$ & 9 & 47.4 & 7 & 50.0 & 24 & 80.0 & 11 & 55.0 & 12 & 46.2 & 63 & 57.8 \\
\hline $\begin{array}{l}3 \text { the Academy has created conditions for } \\
\text { students to participate in creating ideas of } \\
\text { entrepreneurship }\end{array}$ & 4 & 21.1 & 3 & 21.4 & 21 & 70.0 & 10 & 50.0 & 14 & 53.8 & 52 & 47.7 \\
\hline $\begin{array}{l}4 \text { Students have an optimistic spirit, full } \\
\text { of enthusiasm with passion }\end{array}$ & 13 & 68.4 & 12 & 85.7 & 22 & 73.3 & 17 & 85.0 & 22 & 84.6 & 86 & 78.9 \\
\hline $\begin{array}{l}5 \text { The learning programs have a lot of } \\
\text { time for practice and real experience }\end{array}$ & 12 & 63.2 & 7 & 50.0 & 6 & 20.0 & 11 & 55.0 & 14 & 53.8 & 50 & 45.9 \\
\hline $\begin{array}{l}\text { The Academy has organized many } \\
\text { seminars and workshops on the topic } \\
\text { of entrepreneurship among students }\end{array}$ & 5 & 26.3 & 6 & 42.9 & 4 & 13.3 & 8 & 40.0 & 16 & 61.5 & 39 & 35.8 \\
\hline Total & 19 & 100.0 & 14 & 100.0 & 30 & 100.0 & 20 & 100.0 & 26 & 100.0 & 109 & 100.0 \\
\hline
\end{tabular}

Table 3 shows that in indicator 4/ Students have an optimistic spirit, full of enthusiasm and passion accounted for the highest rate at $78.9 \%$, compared to indicator $1 /$ Students have cultivated and learned more professional knowledge rate at $67.0 \%$. In indicator $3 /$ the Academy has created conditions for students to participate in creating ideas of entrepreneurship, the proportion is $47.7 \%$; in indicator 5/ The learning programs have a lot of time for practice and real experience accounted for $45.9 \%$ and the lowest is indicator 6/ The Academy has organized many seminars and workshops on the topic of entrepreneurship accounted for $35.8 \%$.

Indeed, the above description shows that to be successful in your career, you need to have an attitude of confidence and optimism, full of enthusiasm with passion about your chosen job. 
Studying more about social groups revealed more differences, as well as the consensus of groups with reasons for confidence when starting a business. Considering the social groups, the specialized groups are also in Table 3 with significant equals to 0.000 , showing that there is a huge difference between majors in terms of reasons for confidence in starting a business. The authors would like to take two indicators for illustrative analysis: In indicator 4/ Students have an optimistic spirit, full of enthusiasm with passion, major of political science accounted for $85.7 \%$ higher than the rate of Law at $85.0 \%$, the State management accounted for $84.6 \%$, the Party construction and state government accounted for $73.3 \%$, the lowest in the social work major at $68.4 \%$. Or in indicator 6/ The Academy has organized many seminars and workshops on the topic of entrepreneurship of students, the state management major accounted for $61.5 \%$, which is higher than that of the political science at $42.9 \%$, the rate of the law major is $40.0 \%$, the social work rate is $26.3 \%$, the lowest rate is the Party construction and the state government with the rate of $13.3 \%$ (see Appendix A). Conducting an in-depth interview on this issue, a male student said: "Honestly, in the process of starting a business, there are many difficulties and challenges, but when you have confidence in them as well as in yourself, you will start a business successfully" (Male student, major of social work, 22 years old). The author's in-depth interview with a female student showed that: "The knowledge and skills equipped help me grasp the basics to choose a right career" (Female student, state management major, 20 years old). It can be seen that, in addition to the difference in the rate between the indicators on the perception of reasons for confidence, there is also a correlation difference between the specialized groups, that is, this reason depends on each student's perception. Particularly in the group of the student year, age, gender, and region, students have relatively similar choices about reasons for confidently starting a business.

\section{Reasons for not being Confident of Starting a Business}

Table 2 above also shows that $52.5 \%$ of students at Ho Chi Minh Cadre Academy suppose that they are not confident enough to start a business. Therefore, what is the reason for this? Research shows that there are up to 5 reasons that govern and influence not daring to start a business, such as lack of optimism, fear of failure, debt.

\section{Lack of practical experience}

4. Did not acquire foundational skills

3. Lack of professional knowledge

2. Waste of time and effort

1. No optimism, always afraid of failure, debt

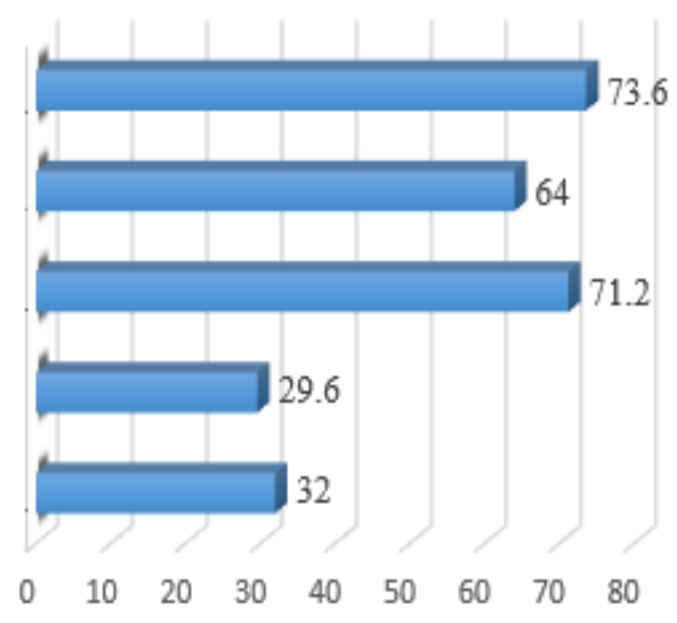

Figure 2. Reasons for not being confident in starting a business Source: Primary source 
Figure 2 shows that the biggest worry of students in starting a business today is the lack of experience. In indicator 5, the reason why students are not confident in starting a business is that they are lack of practical experience and have no leader, and this reason accounted for $73.6 \%$. In indicator 3/ Lack of professional knowledge, the proportion is 71.2\%. In indicator 4/ Not having the necessary background skills in starting a business accounted for $64 \%$. In indicator $1 /$ No optimism, always afraid of failure and debt accounted for $32 \%$ and the lowest rate is in indicator 2/ Waste of time and effort accounted for 29.6\%.

Thereby, the above reasons are quite reasonable and affect the attitude of students participating in entrepreneurship, especially the lack of practical experience and no leader. And to study and analyze more carefully before coming to a conclusion about this, the author has performed Chi-Square Tests between groups to find out the nature of the issue.

Table 3. Reasons for not being confident in starting a business, by majors

\begin{tabular}{|c|c|c|c|c|c|c|c|c|c|c|c|c|}
\hline \multirow{3}{*}{$\begin{array}{l}\text { Reasons for not being confident to start a } \\
\text { business }\end{array}$} & \multicolumn{12}{|c|}{ Major } \\
\hline & \multicolumn{2}{|c|}{ Social Work } & \multicolumn{2}{|c|}{$\begin{array}{l}\text { Political } \\
\text { Science }\end{array}$} & \multicolumn{2}{|c|}{$\begin{array}{c}\text { Party } \\
\text { Construction } \\
\text { and State } \\
\text { Government }\end{array}$} & \multicolumn{2}{|c|}{ Law } & \multicolumn{2}{|c|}{$\begin{array}{c}\text { State } \\
\text { management }\end{array}$} & \multicolumn{2}{|c|}{ Total } \\
\hline & $\mathrm{N}$ & $\%$ & $\mathrm{~N}$ & $\%$ & $\mathrm{~N}$ & $\%$ & $\mathrm{~N}$ & $\%$ & $\mathrm{~N}$ & $\%$ & $\mathrm{~N}$ & $\%$ \\
\hline $\begin{array}{l}1 \text { No optimism, always being afraid of } \\
\text { failure and debt }\end{array}$ & 4 & 14.3 & 10 & 31.3 & 7 & 38.9 & 13 & 52.0 & 6 & 27.3 & 40 & 32.0 \\
\hline 2 Waste of time and effort & 3 & 10.7 & 8 & 25.0 & 14 & 77.8 & 9 & 36.0 & 3 & 13.6 & 37 & 29.6 \\
\hline 3 Lack of professional knowledge & 19 & 67.9 & 23 & 71.9 & 12 & 66.7 & 19 & 76.0 & 16 & 72.7 & 89 & 71.2 \\
\hline 4 Did not acquire foundational skills & 20 & 71.4 & 19 & 59.4 & 9 & 50.0 & 16 & 64.0 & 16 & 72.7 & 80 & 64.0 \\
\hline 5 Lack of practical experience, no leader & 23 & 82.1 & 24 & 75.0 & 5 & 27.8 & 21 & 84.0 & 19 & 86.4 & 92 & 73.6 \\
\hline Total & 28 & 100.0 & 32 & 100.0 & 18 & 100.0 & 25 & 100.0 & 22 & 100.0 & 125 & 100.0 \\
\hline
\end{tabular}

Significant $=0.000$

Source: Primary source

Considering the social group, the major group is also in Table 3 with significant equals 0.000 , showing that there is a difference between the majors. The authors would like to take an indicator for analysis. In indicator 5/ Lack of practical experience and no leader, state management group accounted for $86.4 \%$, Law group represented $84.9 \%$, social work group accounted for $82.1 \%$, political science group at $75.0 \%$ and the lowest in the party construction and the state government accounting for $27.8 \%$ (see Appendix F). It seems that in index 5, only the Party construction group and the state government have a much lower rate compared to the other groups. The question raised here is why do students think that the lack of a leader and lack of practical experience is a decisive factor? When we interviewed a female student, she said: "Starting a business has many failures. If no one shares or advises you what to do, it's easy to get lost. You don't know what to do and where to start. There is no joy but suffering" (A female student, major of party construction and state government, 20 years old).

Regarding the significance of age group equals 0.217 , it shows that there is no difference between the reasons for not being confident to start a business. The authors would like to take some indicators to analyze and clarify the similarity in perception between groups. Meanwhile, in indicator 5/ Lack of practical experience, there is no leader in the age group (21-27) accounting for $75.9 \%$, higher than the age group (19-20) at $71.6 \%$. As for indicator $2 /$ Waste of time and effort, 
the age group from (21-27 years old) accounted for 31.0\%, higher than the age group (19-20 years old) at 28.4\% (see Appendix G). Finding out about this issue, a male student said: "Starting a business takes a long time, it takes years to recover capital. If you're lucky, you can get it back, but if you lose it all, it's like playing! What I want is to be safe in entrepreneurship?" (Male student, party construction and state government, 20 years old). The Significant of gender group is 0.896 , the Significant of region group is 0.147 and finally the significance of the student year group is 0.426, showing that there is no difference between men and women in the reasons why students are not confident to start a business (see Appendix H, I, J). Why is there a perception of the same reasons? To find out about this issue, the authors interviewed a male student: "I'm very poor in knowledge and social issues, so I don't think I'll start a business. (Male student, Political science major, 19 years old), or a female student: "I want to start a business, but I don't have the experience or skills to handle problems when starting a business" (Female student, Party construction and state government major, 20 years old).

\section{CONCLUSION}

Research on students' attitudes towards entrepreneurship up to now, has always played an important role in the country's development programs for the cause of education. To find out the entrepreneurial perception and attitude of students at Ho Chi Minh Cadre Academy, the current research has deeply clarified each aspect and different reasons for the entrepreneurial perception of students.

With the lessons from previous studies of many authors as well as the views and theories in Section 3.1, and the authors' conception of the entrepreneurial attitude in Section 3.2 is very thorough, it is a premise for the authors to survey entrepreneurial attitudes in section 4 of the study. Through the above description, analysis, and explanation, the research has discovered an important feature in students' perception of entrepreneurship - that is, the restructuring of the economic model to a market economy and international integration there is a combination between old types and new types of start-ups. For example, the study also pointed out the social factors affecting the students' entrepreneurial perception. The students' perception is still hesitant facing the options, their attitude is not drastic.

In addition, the perception of students is struggling between the trend of starting a business or not. The perception of the students is very good, but they have an attitude of not daring to start a business. If we put this restructuring in the context of the country in transition - from an agricultural civilization to an industrial and modern civilization, from a subsidy mechanism to a market and integration mechanism, we will see that's inevitable. This is also considered the reason why many students are still afraid and do not have much confidence in starting a business, and some students have never thought of starting their own business.

\section{REFERENCES}

Hang, L. T. M., \& Tung, N. S. (2019). Influence of entrepreneurship training on entrepreneurship intention - A case study at the University of Danang, Journal of Economic Science, 7. Retrieved from https:// tailieumienphi.vn/doc/anh-huong-cua-dao-tao-khoi-nghiep-den-ydinh-khoi-nghiep-tinh-huong-nghien-cuu-t-x9qeuq.html

Minh, L. N. (2019). The reality of some factors affecting the entrepreneurial spirit of students in Hanoi, Journal of Industry and Trade, 2, 177-182. Retrieved from https://repository.vnu.edu.vn/handle/VNU_123/88956 
Prime Minister. (2017). Decision No. 1665/QD-TTg approving the project "Supporting students to start a business by 2025".

Quang, P. H. (2017). The role of entrepreneurship education in students' entrepreneurial intentions, University of Danang, Journal of Education Management, 9, 85-93. Retrieved from https://tailieu.vn/doc/vai-tro-cua-Giao-duc-khoi-nghiep-doi-voi-y-dinh-khoi-suKinh-doanh-cua-sinh-vien-2072049.html

Thu, N. Q., Hoang, T. T., \& Tan, H. K. (2018). The influence of entrepreneurship perception on entrepreneurial behavior of Vietnamese students: The role of target intention and action intention. Ho Chi Minh City Open University Journal of Science, 60(3), 23-36. Retrieved from https://tailieuxanh.com/vn/tlID2068615_anh-huong-nhan-thuc-khoi-nghiep-denhanh-vi-khoi-nghiep-cua-sinh-vien-viet-nam-vai-tro-y-dinh-muc-tieu-va-y-dinh-hanhdong.html

Thu, N. Q., Hoang, T. T., \& Tan, H. K. (2020). Cohesive role in the relationship between students' entrepreneurial intention and behavior, Journal of Economic Development, 28(11), 0425. Retrieved from https://www.123doc.net/document/7073038-vai-tro-cua-yeu-to-ganket-trong-moi-quan-he-giua-y-dinh-va-hanh-en-courage

Tuan, N. A. (2018). Factors affecting young people's entrepreneurial intention in Vietnam. National Scientific Conference, 298-302. Retrieved from https://www.123doc.net/document/5926386-cac-nhan-to-tac-dong-toi-du-dinh-khoinghiep-cua-thanh-nien-o-viet-nam.html

Thao, T. D., \& Linh., N. T. T. (2019). Some factors affecting students' entrepreneurial intention, Journal of Industry and Trade, 3, 9-103. Retrieved from https://123doc.net//document/7320957-mot-so-nhan-to-tac-dong-den-y-dinh-khoinghiep-cua-sinh-vien.html

Tan, H. K., Diem, N. N., \& Minh, N. T. (2019). The role of education in students' entrepreneurship awareness and intention at Binh Duong University of Economics and Technology, Journal of Economy and Technology, 5-19. Retrieved from https://tailieuchung.com/vn/tlID1211102_vai-tro-cua-Giao-duc-doi-voi-nhan-thuc-va-ydinh-khoi-nghiep-cua-sinh-vien-truong- dai-hoc-king-te-ky-thuat-binh-duong.html

Vietnam Chamber of Commerce and Industry, US Agency for International Development. (2018). Report "Vietnam - A Good Land for Startups: Why Not?" Retrieved from https://tailieu.vn/doc/viet-nam-dat-linh-cho-khoi-nghiep-tai-sao-khong--1999979.html 


\section{APPENDICES}

\section{Appendix A: Reasons for students' confidence in starting a business, by majors}

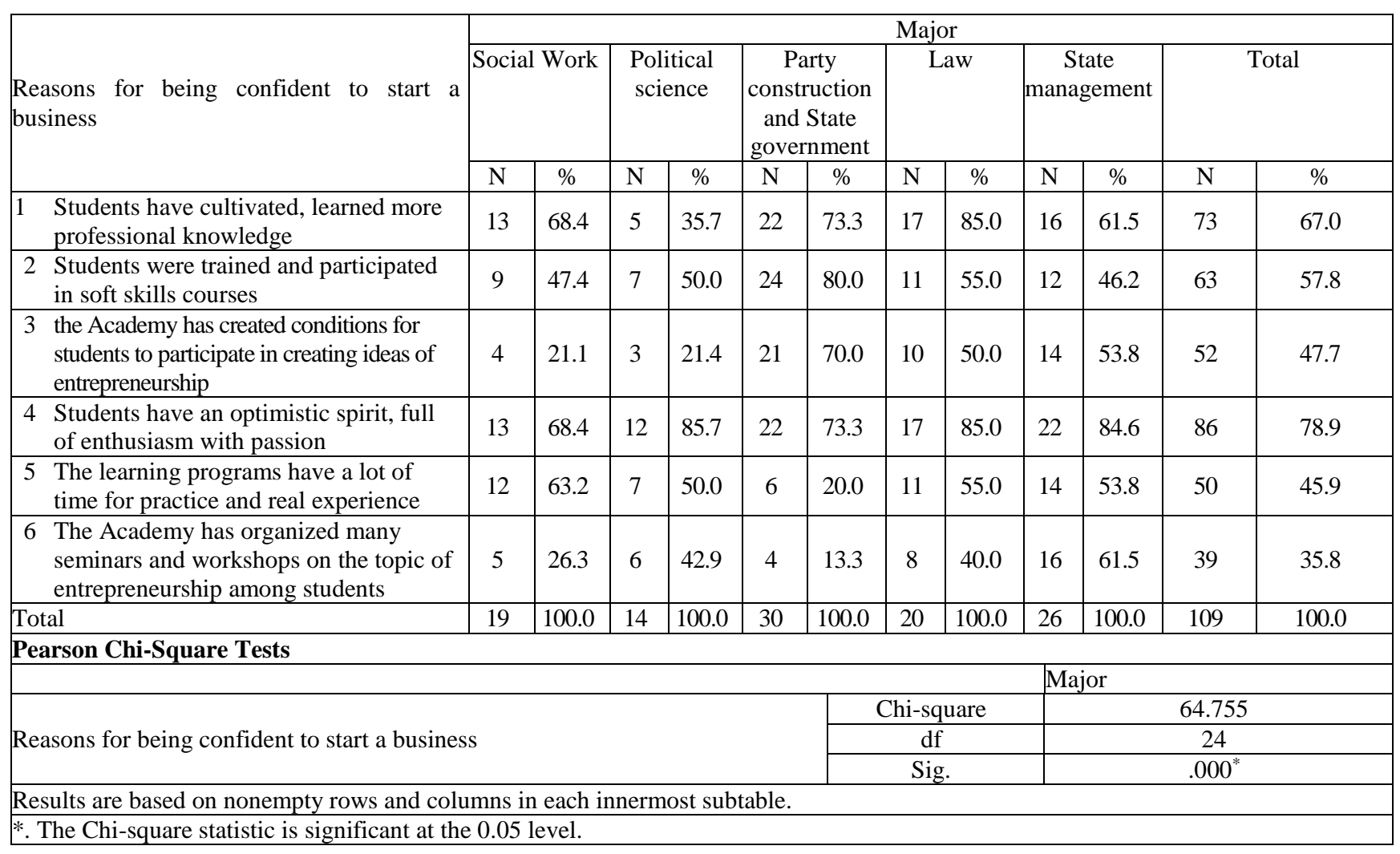

\section{Appendix B: Reasons for students' confidence in starting a business, by age group}

\begin{tabular}{|c|c|c|c|c|c|c|}
\hline \multirow{3}{*}{ Reasons for being confident to start a business } & \multicolumn{6}{|c|}{ Age group } \\
\hline & \multicolumn{2}{|c|}{$\begin{array}{l}\text { From } 19 \text { to } 20 \\
\text { years old }\end{array}$} & \multicolumn{2}{|c|}{$\begin{array}{l}\text { From } 21 \text { to } 27 \\
\text { years old }\end{array}$} & \multicolumn{2}{|c|}{ Total } \\
\hline & $\mathrm{N}$ & $\%$ & $\mathrm{~N}$ & $\%$ & $\mathrm{~N}$ & $\%$ \\
\hline 1. Students have cultivated, learned more professional knowledge & 32 & 65.3 & 41 & 68.3 & 73 & 67.0 \\
\hline 2. Students were trained and participated in soft skills courses & 29 & 59.2 & 34 & 56.7 & 63 & 57.8 \\
\hline $\begin{array}{l}\text { 3. the Academy has created conditions for students to participate in creating } \\
\text { ideas of entrepreneurship }\end{array}$ & 24 & 49.0 & 28 & 46.7 & 52 & 47.7 \\
\hline 4. Students have an optimistic spirit, full of enthusiasm with passion & 39 & 79.6 & 47 & 78.3 & 86 & 78.9 \\
\hline $\begin{array}{l}\text { 5. The learning program has a lot of time for practice and real } \\
\text { experience }\end{array}$ & 25 & 51.0 & 25 & 41.7 & 50 & 45.9 \\
\hline $\begin{array}{l}\text { 6. The Academy organized many seminars and workshops on the } \\
\text { topic of entrepreneurship among students }\end{array}$ & 19 & 38.8 & 20 & 33.3 & 39 & 35.8 \\
\hline Total & 49 & 100.0 & 60 & 100.0 & 109 & 100.0 \\
\hline \multicolumn{7}{|l|}{ Pearson Chi-Square Tests } \\
\hline \multicolumn{7}{|c|}{ Age group } \\
\hline \multirow{3}{*}{ Reasons for being confident to start a business } & \multicolumn{4}{|c|}{ Chi-square } & \multicolumn{2}{|c|}{1.563} \\
\hline & \multirow{2}{*}{\multicolumn{4}{|c|}{\begin{tabular}{|l|} 
Df \\
Sig.
\end{tabular}}} & \multirow{2}{*}{\multicolumn{2}{|c|}{6}} \\
\hline & & & & & & .955 \\
\hline
\end{tabular}


Appendix C: Reasons for students' confidence in starting a business, by gender

\begin{tabular}{|c|c|c|c|c|c|c|}
\hline \multirow{3}{*}{ Reasons for being confident to start a business } & \multicolumn{6}{|c|}{ Gender } \\
\hline & \multicolumn{2}{|c|}{ Female } & \multicolumn{2}{|c|}{ Male } & \multicolumn{2}{|c|}{ Total } \\
\hline & $\mathrm{N}$ & $\%$ & $\mathrm{~N}$ & $\%$ & $\mathrm{~N}$ & $\%$ \\
\hline $\begin{array}{l}\text { 1. Students have cultivated, learned more professional } \\
\text { knowledge }\end{array}$ & 42 & 64.6 & 31 & 70.5 & 73 & 67.0 \\
\hline $\begin{array}{l}\text { 2. Students were trained and participated in soft skills } \\
\text { courses }\end{array}$ & 38 & 58.5 & 25 & 56.8 & 63 & 57.8 \\
\hline $\begin{array}{l}\text { 3. the Academy has created conditions for students to } \\
\text { participate in creating ideas of entrepreneurship }\end{array}$ & 35 & 53.8 & 17 & 38.6 & 52 & 47.7 \\
\hline $\begin{array}{l}\text { 4. Students have an optimistic spirit, full of enthusiasm } \\
\text { with passion }\end{array}$ & 54 & 83.1 & 32 & 72.7 & 86 & 78.9 \\
\hline $\begin{array}{l}\text { 5. The learning program has a lot of time for practice } \\
\text { and real experience }\end{array}$ & 31 & 47.7 & 19 & 43.2 & 50 & 45.9 \\
\hline $\begin{array}{l}\text { 6. The Academy organized many seminars and } \\
\text { workshops on the topic of entrepreneurship among } \\
\text { students }\end{array}$ & 28 & 43.1 & 11 & 25.0 & 39 & 35.8 \\
\hline Total & 65 & 100.0 & 44 & 100.0 & 109 & 100.0 \\
\hline \multicolumn{7}{|l|}{ Pearson Chi-Square Tests } \\
\hline & & & \multicolumn{4}{|c|}{ Gender } \\
\hline \multirow{3}{*}{ Reasons for being confident to start a business } & & & \multicolumn{2}{|c|}{ Chi-square } & \multicolumn{2}{|c|}{8.501} \\
\hline & & & \multicolumn{2}{|c|}{ Df } & \multicolumn{2}{|c|}{6} \\
\hline & & & \multicolumn{2}{|c|}{ Sig. } & \multicolumn{2}{|c|}{.204} \\
\hline
\end{tabular}

\section{Appendix D: Reasons for students' confidence in starting a business, by region}

\begin{tabular}{|c|c|c|c|c|c|c|c|c|}
\hline \multirow{3}{*}{ Reasons for being confident to start a business } & \multicolumn{8}{|c|}{ Region } \\
\hline & \multicolumn{2}{|c|}{ The North } & \multicolumn{2}{|c|}{ The central } & \multicolumn{2}{|c|}{ The South } & \multicolumn{2}{|c|}{ Total } \\
\hline & $\mathrm{N}$ & $\%$ & $\mathrm{~N}$ & $\%$ & $\mathrm{~N}$ & $\%$ & $\mathrm{~N}$ & $\%$ \\
\hline $\begin{array}{l}\text { 1. Students have cultivated, learned more professional } \\
\text { knowledge }\end{array}$ & 8 & 66.7 & 9 & 69.2 & 56 & 66.7 & 73 & 67.0 \\
\hline 2. Students were trained and participated in soft skills courses & 8 & 66.7 & 7 & 53.8 & 48 & 57.1 & 63 & 57.8 \\
\hline $\begin{array}{l}\text { 3. the Academy has created conditions for students to participate in } \\
\text { creating ideas of entrepreneurship }\end{array}$ & 6 & 50.0 & 5 & 38.5 & 41 & 48.8 & 52 & 47.7 \\
\hline $\begin{array}{l}\text { 4. Students have an optimistic spirit, full of enthusiasm with } \\
\text { passion }\end{array}$ & 10 & 83.3 & 11 & 84.6 & 65 & 77.4 & 86 & 78.9 \\
\hline $\begin{array}{l}\text { 5. The learning program has a lot of time for practice and real } \\
\text { experience }\end{array}$ & 6 & 50.0 & 6 & 46.2 & 38 & 45.2 & 50 & 45.9 \\
\hline $\begin{array}{l}\text { 6. The Academy organized many seminars and workshops on } \\
\text { the topic of entrepreneurship among students }\end{array}$ & 1 & 8.3 & 6 & 46.2 & 32 & 38.1 & 39 & 35.8 \\
\hline Total & 12 & 100.0 & 13 & 100.0 & 84 & 100.0 & 109 & 100.0 \\
\hline \multicolumn{9}{|l|}{ Pearson Chi-Square Tests } \\
\hline & & & & \multicolumn{5}{|c|}{ Region } \\
\hline \multirow{3}{*}{ Reasons for being confident to start a business } & & & & \multicolumn{3}{|c|}{ Chi-square } & \multirow{2}{*}{\multicolumn{2}{|c|}{6.379}} \\
\hline & & & & \multirow{2}{*}{\multicolumn{3}{|c|}{$\begin{array}{c}\text { Df } \\
\text { Sig. }\end{array}$}} & & \\
\hline & & & & & & & \multicolumn{2}{|c|}{$\begin{array}{c}12 \\
.896\end{array}$} \\
\hline
\end{tabular}

\section{Appendix E: Reasons for students' confidence in starting a business, by student year}

\begin{tabular}{|c|c|c|c|c|c|c|c|c|c|c|}
\hline \multirow{3}{*}{$\begin{array}{l}\text { Reasons for being confident to start a } \\
\text { business }\end{array}$} & \multicolumn{10}{|c|}{ Student year } \\
\hline & \multicolumn{2}{|c|}{ Freshman } & \multicolumn{2}{|c|}{ Sophomore } & \multicolumn{2}{|c|}{ Junior } & \multicolumn{2}{|c|}{ Senior } & \multicolumn{2}{|l|}{ Total } \\
\hline & $\mathrm{N}$ & $\%$ & $\mathrm{~N}$ & $\%$ & $\mathrm{~N}$ & $\%$ & $\mathrm{~N}$ & $\%$ & $\mathrm{~N}$ & $\%$ \\
\hline $\begin{array}{l}\text { 1. Students have cultivated, learned } \\
\text { more professional knowledge }\end{array}$ & 16 & 59.3 & 16 & 72.7 & 20 & 69.0 & 21 & 67.7 & 73 & 67.0 \\
\hline
\end{tabular}




\begin{tabular}{|l|l|l|l|l|l|l|l|l|l|c|}
\hline $\begin{array}{l}\text { 2. Students were trained and participated } \\
\text { in soft skills courses }\end{array}$ & 14 & 51.9 & 15 & 68.2 & 17 & 58.6 & 17 & 54.8 & 63 & 57.8 \\
\hline $\begin{array}{l}\text { 3. the Academy has created conditions for } \\
\text { students to participate in creating ideas of } \\
\text { entrepreneurship }\end{array}$ & 10 & 37.0 & 14 & 63.6 & 14 & 48.3 & 14 & 45.2 & 52 & 47.7 \\
\hline $\begin{array}{l}\text { 4. Students have an optimistic spirit, full } \\
\text { of enthusiasm with passion }\end{array}$ & 22 & 81.5 & 17 & 77.3 & 24 & 82.8 & 23 & 74.2 & 86 & 78.9 \\
\hline $\begin{array}{l}\text { 5. The learning program has a lot of } \\
\text { time for practice and real experience }\end{array}$ & 11 & 40.7 & 14 & 63.6 & 13 & 44.8 & 12 & 38.7 & 50 & 45.9 \\
\hline $\begin{array}{l}\text { 6. The Academy organized many } \\
\text { seminars and workshops on the topic } \\
\text { of entrepreneurship among students }\end{array}$ & 12 & 44.4 & 7 & 31.8 & 12 & 41.4 & 8 & 25.8 & 39 & 35.8 \\
\hline
\end{tabular}

\section{Appendix F: Reasons for being not confident to start a business, by major}

\begin{tabular}{|c|c|c|c|c|c|c|c|c|c|c|c|c|}
\hline \multirow{3}{*}{$\begin{array}{l}\text { Reasons for being not confident to start a } \\
\text { business }\end{array}$} & \multicolumn{12}{|c|}{ Major } \\
\hline & \multicolumn{2}{|c|}{ Social Work } & \multicolumn{2}{|c|}{$\begin{array}{l}\text { Political } \\
\text { Science }\end{array}$} & \multicolumn{2}{|c|}{$\begin{array}{c}\text { Party } \\
\text { construction } \\
\text { and State } \\
\text { government }\end{array}$} & \multicolumn{2}{|c|}{ Law } & \multicolumn{2}{|c|}{$\begin{array}{c}\text { State } \\
\text { management }\end{array}$} & \multicolumn{2}{|c|}{ Total } \\
\hline & $\mathrm{N}$ & $\%$ & $\mathrm{~N}$ & $\%$ & $\mathrm{~N}$ & $\%$ & $\mathrm{~N}$ & $\%$ & $\mathrm{~N}$ & $\%$ & $\mathrm{~N}$ & $\%$ \\
\hline $1 \begin{array}{l}\text { No optimism, always being afraid } \\
\text { of failure and debt }\end{array}$ & 4 & 14.3 & 10 & 31.3 & 7 & 38.9 & 13 & 52.0 & 6 & 27.3 & 40 & 32.0 \\
\hline 2 Waste of time and effort & 3 & 10.7 & 8 & 25.0 & 14 & 77.8 & 9 & 36.0 & 3 & 13.6 & 37 & 29.6 \\
\hline 3 Lack of professional knowledge & 19 & 67.9 & 23 & 71.9 & 12 & 66.7 & 19 & 76.0 & 16 & 72.7 & 89 & 71.2 \\
\hline 4 Did not acquire foundational skills & 20 & 71.4 & 19 & 59.4 & 9 & 50.0 & 16 & 64.0 & 16 & 72.7 & 80 & 64.0 \\
\hline $\begin{array}{l}5 \text { Lack of practical experience, no } \\
\text { leader }\end{array}$ & 23 & 82.1 & 24 & 75.0 & 5 & 27.8 & 21 & 84.0 & 19 & 86.4 & 92 & 73.6 \\
\hline Total & 28 & 100.0 & 32 & 100.0 & 18 & 100.0 & 25 & 100.0 & 22 & 100.0 & 125 & 100.0 \\
\hline \multicolumn{13}{|l|}{ Pearson Chi-Square Tests } \\
\hline \multicolumn{9}{|l|}{ 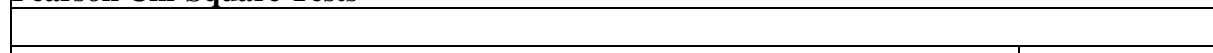 } & \multicolumn{4}{|c|}{ Major } \\
\hline \multirow{3}{*}{\multicolumn{7}{|c|}{ Reasons for not being confident to start a business }} & Chi- & quare & \multirow{2}{*}{\multicolumn{4}{|c|}{$\frac{65.252}{20}$}} \\
\hline & & & & & & & \multirow{2}{*}{\multicolumn{2}{|c|}{$\begin{array}{c}\text { df } \\
\text { Sig. }\end{array}$}} & & & & \\
\hline & & & & & & & & & \multicolumn{4}{|c|}{$\frac{20}{.000^{*}}$} \\
\hline
\end{tabular}

\section{Appendix G: Reasons for not being confident to start a business, by age group}

\begin{tabular}{|l|c|c|c|c|c|c|}
\hline \multirow{2}{*}{ Reasons for being not confident to start a business } & \multicolumn{4}{|c|}{ Age group } \\
\cline { 2 - 7 } & \multicolumn{2}{|c|}{$\begin{array}{c}\text { From } 19 \text { to 20 } \\
\text { years old }\end{array}$} & \multicolumn{2}{|c|}{$\begin{array}{c}\text { From 21 to 27 } \\
\text { years old }\end{array}$} & \multicolumn{2}{c|}{ Total } \\
\cline { 2 - 7 } & $\mathrm{N}$ & $\%$ & $\mathrm{~N}$ & $\%$ & $\mathrm{~N}$ & $\%$ \\
\hline $1 \quad$ No optimism, always being afraid of failure and debt & 26 & 38.8 & 14 & 24.1 & 40 & 32.0 \\
\hline $2 \quad$ Waste of time and effort & 19 & 28.4 & 18 & 31.0 & 37 & 29.6 \\
\hline $3 \quad$ Lack of professional knowledge & 49 & 73.1 & 40 & 69.0 & 89 & 71.2 \\
\hline $4 \quad$ Did not acquire foundational skills & 38 & 56.7 & 42 & 72.4 & 80 & 64.0 \\
\hline $5 \quad$ Lack of practical experience, no leader & 48 & 71.6 & 44 & 75.9 & 92 & 73.6 \\
\hline Total & 67 & 100.0 & 58 & 100.0 & 125 & 100.0 \\
\hline
\end{tabular}




\section{Pearson Chi-Square Tests}

\begin{tabular}{|c|c|c|}
\hline & & Age group \\
\hline \multirow{3}{*}{ Reasons for being not confident to start a business } & Chi-square & 7.054 \\
\hline & df & 5 \\
\hline & Sig. & .217 \\
\hline
\end{tabular}

\section{Appendix H: Reasons for being not confident to start a business, by gender}

\begin{tabular}{|c|c|c|c|c|c|c|}
\hline \multirow{3}{*}{ Reasons for being not confident to start a business } & \multicolumn{6}{|c|}{ Gender } \\
\hline & \multicolumn{2}{|c|}{ Female } & \multicolumn{2}{|c|}{ Male } & \multicolumn{2}{|c|}{ Total } \\
\hline & $\mathrm{N}$ & $\%$ & $\mathrm{~N}$ & $\%$ & $\mathrm{~N}$ & $\%$ \\
\hline 1 No optimism, always being afraid of failure and debt & 29 & 32.2 & 11 & 31.4 & 40 & 32.0 \\
\hline 2 Waste of time and effort & 29 & 32.2 & 8 & 22.9 & 37 & 29.6 \\
\hline 3 Lack of professional knowledge & 63 & 70.0 & 26 & 74.3 & 89 & 71.2 \\
\hline 4 Did not acquire foundational skills & 59 & 65.6 & 21 & 60.0 & 80 & 64.0 \\
\hline 5 Lack of practical experience, no leader & 66 & 73.3 & 26 & 74.3 & 92 & 73.6 \\
\hline Total & 90 & 100.0 & 35 & 100.0 & 125 & 100.0 \\
\hline
\end{tabular}

\begin{tabular}{|l|c|c|}
\hline \multicolumn{2}{|l|}{ Pearson Chi-Square Tests } & Gender \\
\hline \multirow{2}{*}{ Reasons for being not confident to start a business } & Chi-square & 1.643 \\
\cline { 2 - 3 } & df & 5 \\
\cline { 2 - 3 } & Sig. & .896 \\
\hline
\end{tabular}

\section{Appendix I: Reasons for being not confident starting a business, by region}

\begin{tabular}{|c|c|c|c|c|c|c|c|c|}
\hline \multirow{3}{*}{ Reasons for being not confident to start a business } & \multicolumn{8}{|c|}{ Region } \\
\hline & \multicolumn{2}{|c|}{ North } & \multicolumn{2}{|c|}{ Central } & \multicolumn{2}{|c|}{ South } & \multicolumn{2}{|c|}{ Total } \\
\hline & $\mathrm{N}$ & $\%$ & $\mathrm{~N}$ & $\%$ & $\mathrm{~N}$ & $\%$ & $\mathrm{~N}$ & $\%$ \\
\hline $\begin{array}{l}1 \text { No optimism, always being afraid of failure and } \\
\text { debt }\end{array}$ & 4 & 25.0 & 10 & 40.0 & 26 & 31.0 & 40 & 32.0 \\
\hline 2 Waste of time and effort & 2 & 12.5 & 13 & 52.0 & 22 & 26.2 & 37 & 29.6 \\
\hline 3 Lack of professional knowledge & 9 & 56.3 & 17 & 68.0 & 63 & 75.0 & 89 & 71.2 \\
\hline 4 Did not acquire foundational skills & 10 & 62.5 & 15 & 60.0 & 55 & 65.5 & 80 & 64.0 \\
\hline 5 Lack of practical experience, no leader & 11 & 68.8 & 16 & 64.0 & 65 & 77.4 & 92 & 73.6 \\
\hline Total & 16 & 100.0 & 25 & 100.0 & 84 & 100.0 & 125 & 100.0 \\
\hline \multicolumn{9}{|l|}{ Pearson Chi-Square Tests } \\
\hline & & & & & & & \multicolumn{2}{|c|}{ Region } \\
\hline \multirow{3}{*}{ Reasons for being not confident to start a business } & & & & & \multicolumn{2}{|c|}{ Chi-square } & \multicolumn{2}{|c|}{14.598} \\
\hline & & & & & \multicolumn{2}{|c|}{ df } & \multicolumn{2}{|c|}{10} \\
\hline & & & & & \multicolumn{2}{|c|}{ Sig. } & \multicolumn{2}{|c|}{.147} \\
\hline
\end{tabular}

\section{Appendix J: Reasons for being not confident to start a business, by student year}

\begin{tabular}{|c|c|c|c|c|c|c|c|c|c|c|}
\hline \multirow{3}{*}{$\begin{array}{l}\text { Reasons for being not confident to start a } \\
\text { business }\end{array}$} & \multicolumn{10}{|c|}{ Student year } \\
\hline & \multicolumn{2}{|c|}{ Freshman } & \multicolumn{2}{|c|}{ Sophomore } & \multicolumn{2}{|c|}{ Junior } & \multicolumn{2}{|c|}{ Senior } & \multicolumn{2}{|c|}{ Total } \\
\hline & $\mathrm{N}$ & $\%$ & $\mathrm{~N}$ & $\%$ & $\mathrm{~N}$ & $\%$ & $\mathrm{~N}$ & $\%$ & $\mathrm{~N}$ & $\%$ \\
\hline $\begin{array}{l}1 \text { No optimism, always being afraid of } \\
\text { failure and debt }\end{array}$ & 12 & 37.5 & 14 & 38.9 & 6 & 19.4 & 8 & 30.8 & 40 & 32.0 \\
\hline 2 Waste of time and effort & 8 & 25.0 & 11 & 30.6 & 9 & 29.0 & 9 & 34.6 & 37 & 29.6 \\
\hline
\end{tabular}




\begin{tabular}{|l|l|l|l|l|l|l|l|l|l|c|c|}
\hline 3 Lack of professional knowledge & 23 & 71.9 & 26 & 72.2 & 20 & 64.5 & 20 & 76.9 & 89 & 71.2 \\
\hline 4 Did not acquire foundational skills & 23 & 71.9 & 16 & 44.4 & 21 & 67.7 & 20 & 76.9 & 80 & 64.0 \\
\hline 5 Lack of practical experience, no leader & 24 & 75.0 & 25 & 69.4 & 22 & 71.0 & 21 & 80.8 & 92 & 73.6 \\
\hline
\end{tabular}

\section{Copyrights}

Copyright for this article is retained by the author(s), with first publication rights granted to the journal. This is an open-access article distributed under the terms and conditions of the Creative Commons Attribution license (http://creativecommons.org/licenses/by/4.0) 